\title{
CORPORATE SOCIAL RESPONSIBILITY IN HEALTH SECTOR: A CASE STUDY IN THE GOVERNMENT HOSPITALS IN MEDAN, INDONESIA
}

\author{
Arlina Nurbaity LUBIS \\ Faculty of Economics and Business, Universitas Sumatera Utara, Medan, 20155 Indonesia \\ E-mail: arlinalubis10@gmail.com
}

Received 14 December 2017; accepted 06 March 2018

\begin{abstract}
Contemporary society demands that every organization operate with a sense of social responsibility. Many organizations now include corporate social responsibility (CSR) activities in their work programs. In the health sector, however, the role of CSR has not been studied as intensively as in private corporations because the services provided by the health sector are already valued as directly serving humanity. This research aims to evaluate the impact of CSR on the health sector, specifically on government hospitals. This model was developed by analyzing the influence of CSR on hospital reputation, customer loyalty, and hospital values. By answering questionnaires, a total of 200 hospital patients from four government hospitals participated in the study. The proposed model was evaluated using path analysis with AMOS tools. The results of this study provide empirical evidence that overall, CSR positively affects the reputation of the hospital, patient loyalty, and hospital value. Although there is a direct negative effect of CSR on hospital value, the larger influence of indirect effect that occurs through the mediating role of reputation and patient loyalty variables shows that CSR is able to increase the hospital value. Practically, these results imply that CSR should be applied as a strategic tool in improving the value of the hospital.
\end{abstract}

Keywords: corporate social responsibility, hospital reputation, customer loyalty, hospital value.

JEL Classification: H75, L20, M14.

\section{Introduction}

Corporate social responsibility (CSR) refers to a company's strategic actions in carrying out its business activities in an ethical and social sphere (Aguilera et al. 2007, Tai and Chuang 2014). The core concept of CSR is related to empowering stakeholders and taking advantage of available resources in business activities (Bhattacharya et al. 2009). The scope of CSR activities is diverse, ranging from cooperation, maintaining good relationships with employees and other stakeholders, and even activities in protecting the environment (Ismail 2009, Babiak and Trendafilova 2011, Frynas 2009, Torugsa et al. 2013).

The classical view of CSR only focused on charitable activities or solving social problems. Nowadays, this paradigm has shifted as the business responsibility to solve environmental and social problems (Handayani et al. 2017, Lee 2008, Secchi 2007). The CSR scheme proposed by Carroll (1991) indicates that the elements of volunteering and charity in CSR activities are just a small portion of a series of organizational goals. The concentric circles of CSR state that CSR is an organizational obligation to create a better life (Geva 2008). CSR is an important marketing tool that is largely considered able to promote the company's competitive advantage, reputation, and performance in both private and government-owned companies.

CSR activity is perceived as being able to generate an organization's good reputation among stakeholders in the long term (Susanto 2009). In the context of hospital service, the implementation of CSR is generally performed in line with hospital operations. CSR activities conducted in hospitals involving patients are able to create perceptions in the minds of patients (Boshoff and Gray 2004, Tian et al. 2011, Mostafa 2005). However, unlike CSR activities in the private sector that mainly focus on outside working environment (Handayani et al. 2017), hospital CSR activities

Copyright $\odot 2018$ The Authors. Published by VGTU Press.

This is an Open Access article distributed under the terms of the Creative Commons Attribution License (http://creativecommons.org/licenses/by/4.0/), which permits unrestricted use, distribution, and reproduction in any medium, provided the original author and source are credited.. 
that are conducted outside of the focus of healthcare activities are deemed to disrupt the services. By considering some aspects related to public awareness of the healthcare sector, this study attempts to empirically evaluate the effect of CSR on hospital value, reputation, and loyalty of patients in state-owned hospitals in Medan City, Indonesia. This study is valuable and has novelty due to the fact that CSR is generally done by the private sector (e.g. Khan 2010, Lima Crisóstomo et al. 2011, Fifka 2012, Snider et al. 2003). As a result of CSR usually being confined to the private sector, its practice in both government-owned agencies and healthcare sector has attracted less attention. Publication of CSR activities of private sector hospitals encourages public trust in the use of private services rather than government agencies, such as public hospitals (Pivato et al. 2008). This leads to the phenomenon where private healthcare services have a higher demand than that of government-owned hospitals. This has encouraged the local government to start to implement CSR in the regional hospitals they own. In the last three years, government hospitals in Indonesia have consistently performed CSR activities such as free eye treatment and public health education, including healthy lifestyle activities targeting a range of people from elementary school children to students in higher education. For instance, the government hospitals in Medan City have been implementing such activities for the last three years. This study was driven by the interesting question of the extent to which the CSR in government hospitals is able to affect reputation, value, and customer loyalty. This ultimately is expected to have an effect on hospital performance in both satisfaction of customer and financial benefit. This study attempts to provide an insightful overview that focuses on the patient's perspective in evaluating the impact of CSR activities implemented by government hospitals, rather than focus on internal assessment of hospital service. Moreover, this study is unique in that it investigates CSR in the healthcare sector which is considerably different from previous studies that give more emphasis to the private sector.

\section{Literature review}

\section{Corporate social responsibility and hospital reputation}

Schermerhorn (2016) and Kurniawan (2017) states that generally there are four levels of CSR actions: profitability, legitimacy, ethics, and philanthropy. These four are grouped into two main groups. The first group deals with the scope of the company's obligations that intersect with applicable law. The other group relates to the persuasive sphere leading to voluntary action. CSR is regarded as one of the most instrumental factors in beating the competition in the market (Wall 2008). Now, the community is also strongly reacting to CSR activities that are considered beneficial to the community. CSR activities in the context of hospitals generally relate to the education of paramedical teams, health seminars, and charity activities for the public to improve public health in general. CSR will strengthen the reputation of the hospital as CSR activities conducted by the hospital increase. Some studies, such as those by Susanto (2012) and Gazzola (2014), identify a strong relationship between CSR and the company's reputation. Moreover, Inleh, Bartlett, and May's (2011) study reveals that one of the reasons companies do CSR is that they do not lose public reputation.

Doda’s (2015) study suggest a link between CSR practices and corporate reputation. This value is gained through a comprehensive set of actions, involving consumers, internal human resources, client networks and innovation exploration to add value to CSR practices. Dean (2003) provides empirical evidence of a positive relationship between reputation moderated by certain types of donations with CSR practices. McWilliams, A. (2000) states that CSR can be used as a means to enhance the company's reputation. Other studies provide similar evidence (e.g Morsing and Schultz 2006, Kotler and Lee 2008, Lai et al. 2010). More specifically in the health sector, Bear et al. 2010) suggest that CSR ratings is less likely able to have a significant effect in the relationship between gender diversification in the board of directors and corporate reputation. Clarke and GibsonSweet, (1999) disclose that firms with high levels of public scrutiny, as in the health sector, tend to use annual reports to improve the reputation of the community.

\section{Corporate social responsibility and customer loyalty}

Previous studies have suggested that loyalty plays an important role in the long-term growth and sustainability of a company's business. Loyalty becomes more than the ultimate goal of marketing (Mandhachitara and Poolthong 2011). In line with the concept of consumer behavior, consumers would be more loyal to products that contain ethical elements and companies that consistently implement CSR activities. Consumers consider CSR actions a factor in evaluating the product of a company that leads to loyal behavior (Öberseder et al. 2013). In this context, the hospitals must consistently implement and budget CSR activities in an effort to reach consumer loyalty.

Furthermore, a study from Vlachos et al. (2009) which states that profit motive-based CSR has negative effect on overall CSR value, has relevance and implication on health sector, which generally implement social and humanity based CSR (Grandón and Reinoso 2016, Mukhopadhyay et al. 2014). In relation to loyalty, many studies show that CSR is more likely able to increase the consumer loyalty (García de los Salmones Sánchez et al. 2005). Whereas, Sen and Bhattacharya (2001) reveal that under certain circumstances, CSR is able to reduce consumer interest in using company products. The model developed by Luo and 
Bhattacharya (2006) demonstrates the relationship between CSR and customer satisfaction, which in turn can increase the market value of the company.

\section{Corporate social responsibility and hospital value}

People are now increasingly conscious of human rights and ethical behaviors which impacts the strong potential influence of a company's CSR activities. Brandao et al. (2013) reveal a new paradigm for an approach to social responsibility in hospital management in which hospitals can perform CSR activities actively or passively. The approach to social responsibility that has been developed and implemented by the private sector can now benefit the health services sector such as hospitals (Semplici 2011). In a competitive market, the proper implementation of CSR will likely increase the value of the hospital as CSR actions will improve the effectiveness and efficiency in providing health services (Brandao et al. 2013).

CSR activities can attract the attention of workers as well as shape the behavior expected of patients and paramedics. This will encourage increased effectiveness and efficiency of health services provided. However, some previous researchers indicated that CSR has no impact or even a negative effect on the value of the hospital. Gherghina and Vintila (2016) show that there was no relationship between CSR and corporate value, particularly in the form of CSR stakeholders. In that study, the CSR activity was focused on environmental conservation. Communities are more receptive to CSR actions related to the environment than other forms such as education and counseling. Srivastava et al. (2012) asserts that CSR does not always bring increased value and is even likely to decrease the consumer's perceived value of the company. Since poorly implemented CSR actions may impair perceptions of value, the company's social responsibility to the environment in this case should be applied wisely.

\section{Hospital reputation and customer loyalty}

Marketing literature suggests that customers evaluate their perceived performance of a corporation and its product based on its reputation. A stronger reputation will gain more trust and customer loyalty (Keh and Xie 2009, Shirazi et al. 2013, Wahyuni and Ginting 2017). Brand identification theory also suggests that there is a positive relationship between corporate reputation and customer loyalty. Hence, a well-known product will be more likely accepted by newcomers (Marin et al. 2009).

A study from Bontis, Booker, and Serenko (2007) and Budiharseno (2017) suggest that reputation affects loyalty. Weiwei (2007) and Nugroho et al. (2017) state that with respect to the nature of intangible in service business, the use of the company's physical aspects, direct contact and communication is necessary to build a reputation for increasing consumer loyalty. In addition, some studies (Helm et al. 2010, Walsh et al. 2009) also reveal direct relationship between company reputation and loyalty. In the context of health sector, Boshoff and Gray (2004), Wu (2011) and Naidu (2009) show that assurance and the service quality of hospital nurses has a positive impact on both satisfaction and patient loyalty.

\section{Hospital reputation and hospital value}

As an action based on a cost-benefit analysis, CSR should be able to increase the company's value through the creation of reputation and competitive advantage in the long term. However, the current study still does not provide sufficient evidence that CSR is likely able to increase the value of the company as a whole. For instance, Doda (2015) shows that CSR activities do not have an impact on company value. CSR is no longer just about social charity; it has become an effective marketing tool used to promote the image and value of the company (Folajin et al. 2014, Geva 2008).

The relationship between the reputation and value of a company has been identified as a valued relationship (Knight and Pretty 2001). Companies that have a high reputation will likely attract the attention of better resources that can be used in increasing the value of the company. Moreover, consumer perceptions of company value will increase in well-known companies compared to those which are lesser known. Haghkhah et al. (2013) states that reputation is a source of growth and development in an enterprise. Nicklin and Dickson (2009) state that reputation in the form of hospital accreditation plays an important role in the perception of the value of a hospital to the public.

\section{Customer loyalty and hospital value}

Many findings of previous studies suggest that companies carry out CSR activities to practically gain an edge and sustainable growth in the long term (Carroll and Shabana 2010, Korkchi and Rombaut 2007, Nasieku et al. 2014). However, it is worth noting that CSR may not solely achieve decisive long-term benefits for the company; it is considered to have costs as well. CSR activities require a certain amount of costs to be incurred by the company. Some studies argue that CSR will not likely be able to increase the value of the company because of its very high level of uncertainty. Four percent of the economic intelligence units consider CSR to be entirely detrimental to the company (Lev 2013).

In the health sector, such as in hospitals, the healthcare provider's reputation has an important role in attracting the attention of consumers to use the health services provided, in addition to attracting awareness from others in the health 
sector. This may be because a good reputation, for example in terms of a healthcare provider's service and hygiene, is considerably demanded by users. Most people will very likely not want to use the services of a hospital that does not have a good reputation. Most importantly, the hospital users will pay attention to hospital services and quality problems, especially regarding hospital success rate and risk of treatment failure (Meyer et al. 2004). The patient's loyalty to the hospital also plays an important role in achieving long-term growth. Marketing experts identify that one of the expected behaviors of loyal consumers is the consumption of services rendered, or the use of repeat services in the future (Kotler and Keller 2012).

Kotler and Keller (2012) state that customer loyalty is the key to achieving long-term growth and business continuity. The cost of acquiring new customers is generally five times more expensive than maintaining existing customers. Moreover, loyal customers will invite new prospects at no additional cost. It becomes a potential for generating profits for the company in the long term. The generated profits could be used as investment to increase effectiveness and efficiency of existing services that have an impact on better value.

\section{Research model and hypotheses}

In line with the literature study conducted, the research model was developed to meet the objectives of this study. The model proposed in this study is summarized in Figure 1.

In accordance with the proposed model, this study proposed eight hypotheses as follows:

$-\mathrm{H}_{1}$ : There is a direct positive influence of CSR on hospital reputation

- $\mathrm{H}_{2}$ : There is a direct positive influence of CSR on customer loyalty

- $\mathrm{H}_{3}$ : There is a direct positive influence of CSR on hospital value

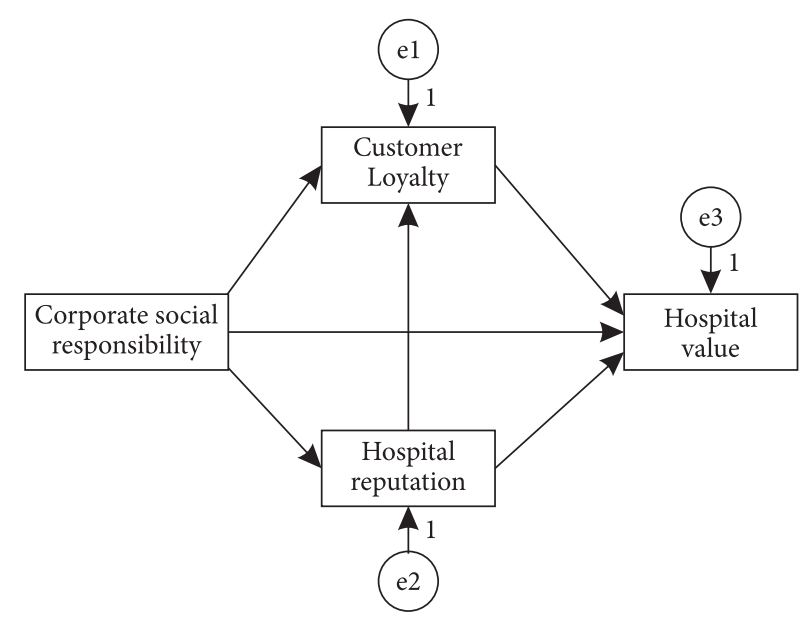

Figure 1. The proposed model of CSR impact in government hospital
- $\mathrm{H}_{4}$ : There is a direct positive influence of hospital reputation on customer loyalty

$-\mathrm{H}_{5}$ : There is a direct positive influence of customer loyalty on hospital value

$-\mathrm{H}_{6}$ : There is a direct positive influence of hospital reputation on hospital value

$-\mathrm{H}_{7}$ : There is a mediating role of hospital reputation in strengthening the relationship between CSR and hospital value

$-\mathrm{H}_{8}$ : There is a mediating role of customer loyalty in strengthening the relationship between CSR and hospital value

\section{Research method}

\section{Participants}

This study focuses on the patient's perspective in evaluating the impact of CSR activities imposed by government hospitals. Therefore, the sample criteria are the patients who know the CSR activity of the hospital. According to Ghozali (2011), the minimum sample criterion for a path analysis is $200-300$. To get representative samples from each hospital, 50 inpatients from each one were randomly invited to participate in this study. Participants were invited randomly according to the list of patients present in each hospital. If a selected sample was not willing to participate in the study or was unable to participate because the selected sample was out-patient, the sample would be replaced with a randomly selected sample that met the minimum requirements. In this study, all selected samples were able to participate.

\section{Location and time of research}

In terms of research location, this study was conducted in the city of Medan, North Sumatra, that has four government hospitals: Putri Hijau Hospital, Haji Hospital, Pirngadi Hospital, and Adam Malik Hospital. This study was conducted from June to September, 2017.

\section{Research scheme}

The researcher visited four government hospital in Medan to conduct the research. As the researcher visited, the participants were gathered in the hall. Researcher give the basic knowledge of CSR activities conducted in hospital, loyalty, reputation, and value to the participants before collecting the data. The researcher was accompanying the patients in case they had a question about the statements.

\section{Data collection}

This research was conducted using questionnaires as the source of the data acquisition about patient perception of the variables. Questionnaires were arranged based on the 
literature review and adjusted in line with the current situation in government hospitals in Medan City. The study also interviewed inpatients who were randomly selected in an effort to obtain specific information regarding the actual situation in the government hospitals. Documentation was also conducted in an effort to obtain the necessary data in discussing this research.

\section{Validity and reliability}

The distributed questionnaire has passed the validity test, tested by Pearson Correlation, as well as a test of the reliability of the instrument by using Cronbach's Alpha. Both instruments were used to ensure that the data measured through the questionnaire is accurate and correct in measuring each variable. The research questionnaires were prepared with operationalization as shown in Table 1.

\section{Data analysis technique}

Data in this research was analyzed by using path analysis with regression method. The statistical tool used in assessing the path coefficient estimation was the Analysis of Moment Structures (AMOS). A Likert scale was used to measure the patient's perception of research variables. The variable score of each patient is the average value of each variable with the consideration of the number of different indicators for each variable.

This research proposes a CSR model with the assumption that CSR is able to affect the reputation of the hospital, patient loyalty, and the value of government hospitals. Reputation and loyalty both serve as mediating variables in an effort to increase the value of the hospital. This study evaluated direct, indirect, and total influence of the CSR on the hospital reputation, loyalty, and hospital value. The direct, indirect, and total influence were estimated by AMOS software, while the estimate of the significance of the indirect effect, of the relationship between the CSR hospital reputation - hospital value, and between the CSR the customer loyalty - hospital value was evaluated by using Sobel Test (Sobel 1982).

\section{Result and discussion}

\section{Descriptive statistics}

This study used descriptive statistical analysis to evaluate the perceptions of inpatients about CSR practices that have been implemented by hospitals, patient loyalty levels, hospital reputation, and their perception of overall hospital values. The value used is based on the average score of each variable. The value of the mean or average score used was to avoid score bias due to an unequal number of indicators in each variable. The descriptive statistical tools used in the analysis are the maximum, minimum, average, and
Table 1. Operational definition and instrument reliability

\begin{tabular}{|l|l|c|c|}
\hline Variables & Operational definition & $\begin{array}{c}\text { Number of } \\
\text { Indicators }\end{array}$ & $\begin{array}{c}\text { Cronbach's } \\
\text { Alpha }\end{array}$ \\
\hline $\begin{array}{l}\text { Corpo- } \\
\text { rate Social } \\
\text { Respon- } \\
\text { sibility }\end{array}$ & $\begin{array}{l}\text { Patients' perceptions } \\
\text { of the actions of } \\
\text { social responsibility } \\
\text { applied by the hospital }\end{array}$ & 6 & 0.871 \\
\hline $\begin{array}{l}\text { Hospital } \\
\text { Repu- } \\
\text { tation }\end{array}$ & $\begin{array}{l}\text { Patient perception of } \\
\text { hospital health care } \\
\text { image }\end{array}$ & 14 & 0.735 \\
\hline $\begin{array}{l}\text { Patients' } \\
\text { Loyalty }\end{array}$ & $\begin{array}{l}\text { Consumer behavior } \\
\text { that shows repurchase, } \\
\text { retain, and recom- } \\
\text { mend attitudes }\end{array}$ & 19 & 0.722 \\
\hline $\begin{array}{l}\text { Hospital } \\
\text { Value }\end{array}$ & $\begin{array}{l}\text { Perception of hospital } \\
\text { values based on finan- } \\
\text { cial aspects, effective- } \\
\text { ness, and efficiency of } \\
\text { health services }\end{array}$ & 9 & 0.924 \\
\hline
\end{tabular}

Table 2. Descriptive Statistics Result

\begin{tabular}{|l|c|c|c|c|}
\hline \multicolumn{1}{|c|}{ Variable } & Min & Max & Mean & Deviation \\
\hline Hospital's CSR & 1.00 & 5.00 & 3.13 & 1.08 \\
\hline $\begin{array}{l}\text { Hospital } \\
\text { Reputation }\end{array}$ & 1.60 & 4.60 & 3.70 & 0.54 \\
\hline $\begin{array}{l}\text { Customer } \\
\text { Loyalty }\end{array}$ & 1.50 & 4.50 & 3.53 & 0.60 \\
\hline $\begin{array}{l}\text { Hospital } \\
\text { Perceived Value }\end{array}$ & 1.30 & 4.30 & 3.73 & 0.57 \\
\hline
\end{tabular}

standard deviation values. Descriptive statistical results are summarized in Table 2.

Table 2 shows that inpatients assessed perceived the level of implementation of CSR at government hospitals as relatively good with an average score of 3.13 from a five-point Likert scale. The level of the standard deviation (STDEV = 1.08) indicates that the response of the patient varies considerably. Many implementations of CSR applied by government hospitals are not well perceived by the patient. A high range of answers confirm that although there are patients who are perceive CSR programs as very good, some do not feel the same way. They did not respond well to the CSR program that the hospital applied.

Table 2 also indicates that the general reputation of the hospital for patients has been good with an average score of 3.70 on a scale of 5.00 . The hospital is perceived to have a good image in the public. This is a good sign for the managerial practices of CSR of government hospitals, indicated by a small value of standard deviation. In line with the reputation, generally inpatients of government hospitals have a high level of loyalty. This is likely to enable the hospital management to expect future visits from these patients 
when they need health services or even advise others to seek treatment at the hospital. With regard to the hospital value, inpatients in the study on average consider that the value of public hospitals is relatively good. This assessment is based on three main aspects, namely financial services, effectiveness, and efficiency of hospital services rendered.

\section{Path analysis}

The model evaluation performed using a path analysis with AMOS identified that CSR only explained 7.7 per cent of the variance of hospital patient loyalty. Moreover, CSR and the hospital reputation together account for 71 per cent of the variance of patient loyalty. In this case, reputation plays a major role in explaining the loyalty of the patient. In connection with the value of the hospital, the three variables of CSR, customer loyalty, and hospital reputation are able to explain 66 per cent of variance. Based on the statistical value of squared multiple correlation, the model proposed in this research is able to predict the impact of CSR on the government hospitals in Medan City.

The results of the estimation of the AMOS diagram used in evaluating the research model are presented in Figure 2. The results of the estimated value and hypothesis testing of direct influence between variables are summarized in Table 3.

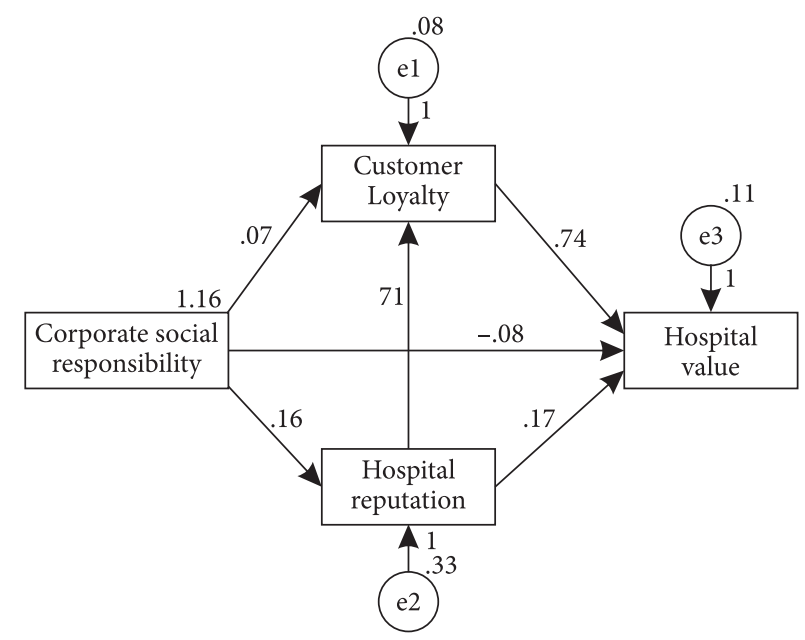

Figure 2. AMOS path for estimate of CSR impact model

\section{The direct effect}

Table 3 indicates that CSR has a positive and significant impact on the reputation of the government hospitals, indicated by the statistical result of hypothesis one of critical ratio (C.R) 3.282 and p-value 0.001 . Hence, there is statistical evidence to suggest that the more appropriately the CSR is applied and well-perceived by the patient, the higher the reputation the hospital gains. Since the first hypothesis is supported by statistical analysis, the hypothesis one stating that there is a direct and positive influence of CSR on the hospital reputation is accepted.

The statistical analysis reveals that CSR has a positive and significant effect on the loyalty of inpatients, indicated by the value of C.R and p-value of hypothesis two of 2.970 and 0.00 , respectively. Accordingly, hypothesis two stating the effect of CSR on customer loyalty is accepted. This allows that patients will likely become more loyal as CSR activity is implemented by the government hospitals.

Hypothesis three tests the effect of CSR activities on the hospital value. The statistical testing reveals that there is a negative and significant impact of CSR on the value of the hospital, indicated by the negative value of C.R -2.905 . Although the relationship is significant, the negative sign proves that there is no direct influence of CSR on the hospital value. Therefore, hypothesis three testing the influence of CSR on the hospital value is not statistically supported.

Furthermore, Table 3 shows that the reputation of the hospital is more likely perceived to have a positive effect on loyalty of patients. This is supported by the statistical result of C.R and p-value of 16.014, and 0.000, respectively. This result statistically supports hypothesis four stating that CSR has a direct and positive influence on the patient loyalty in hospital governments in Medan City. It means that the more CSR programs are implemented by hospital governments, the higher the customer loyalty will be.

Hypothesis five tests the impact of the hospital reputation on the hospital value. The statistical testing reveals that the reputation of hospital is likely perceived to have a positive and significant impact on the value of the government hospitals. This is indicated by the value of C.R of 1.983, and

Table 3. Path analysis estimate and hypothesis testing

\begin{tabular}{|l|l|c|l|c|c|c|c|c|}
\hline \multicolumn{3}{|c|}{ Hypotheses } & \multicolumn{2}{c|}{ Estimate } & S.E & C.R & p-value & Result \\
\hline H1 & Reputation & $\leftarrow$ & CSR & 0.155 & 0.047 & 3.282 & 0.001 & Accepted \\
\hline H2 & Loyalty & $\leftarrow$ & CSR & 0.073 & 0.025 & 2.970 & 0.003 & Accepted \\
\hline H3 & Value & $\leftarrow$ & CSR & -0.084 & 0.029 & -2.905 & 0.004 & Rejected \\
\hline H4 & Loyalty & $\leftarrow$ & Reputation & 0.707 & 0.044 & 16.014 & $* * *$ & Accepted \\
\hline H6 & Value & $\leftarrow$ & Reputation & 0.173 & 0.087 & 1.983 & 0.047 & Accepted \\
\hline H5 & Value & $\leftarrow$ & Loyalty & 0.735 & 0.100 & 7.319 & $* * *$ & Accepted \\
\hline
\end{tabular}

$* * *$ significant at $<1 \%$ 
significance level of 0.047. Accordingly, the hypothesis five is statistically supported. It means that the higher the hospital' reputation, the higher the hospital value.

Finally, hypothesis six tests the influence of customer loyalty on the hospital value. The statistical analysis shows that there is a positive and significant impact of customer loyalty on the value of government hospitals, indicated by the value of C.R of 7.319, and p-value of 0.000 , meaning that the more loyal patients in the hospital are more likely to perceive increased value of the hospital.

\section{The indirect effect}

In order to evaluate the indirect effect of both mediating variables of hospital reputation and customer loyalty in strengthening the relationship between CSR programs and the hospital value, this study used the Sobel test. The test results of the Sobel test are summarized in Table 4.

Table 4 shows the indirect effect of CSR on the hospital value through the mediating role of hospital reputation. The result of Sobel test, indicated by the p-value of 0.006 demonstrates that there is a positive and significant impact of CSR on the hospital value. This means that the mediating variable of customer loyalty is able to strengthen the relationship between CSR and the hospital value. Moreover, the relationship is likely to be stronger after the mediating variable of reputation is included, indicated by the $p$-value of 0.000 , and the value of indirect effect of 0.161 . This means that the reputation together with loyalty has a considerable role in an effort to increase the level of the hospital value by conducting CSR activities. The CSR, henceforth, is better able to enhance the reputation of government hospitals that will ultimately improve the patient's perception of the value of the hospital. Accordingly, the hypotheses seven and eight are statistically supported.

\section{Total effect}

The CSR Impact model proposed in this study provides the indirect effect of CSR on the value of government hospitals. Both the reputation and the loyalty of the patient are also proved to significantly play a role as intermediary variables that have an intervening effect on CSR in increasing the hospital value. The direct, indirect, and total influence are summarized in Table 5 .

Table 5 shows that although directly CSR has a negative impact on the hospital value, overall, CSR is more able to increase the hospital value by inserting the mediating role of the hospital reputation and patient loyalty.

\section{Discussion}

\section{Direct effect of CSR on hospital reputation}

The results indicate that CSR activities conducted by government hospitals will likely be able to improve the reputation of the hospital. According to reputation management, an organization had to carefully set policy and action in order to create hospital reputation among stakeholder in long-term (Susanto 2009). Our findings support the fact that many organization commit to do CSR due to threat of losing reputation for long term (Inleh et al. 2011). Susanto (2012) and Gazzola (2014) also stated that CSR will enhance organization's reputation. Any CSR activity that is announced or published will have more impact on the company's stakeholders. The community now has a very high awareness of the "green-activities" and CSR activities undertaken by the company, especially CSR that supports the welfare of stakeholders in general. In this study, patients were asked to respond to a credible form of CSR that has been implemented by the hospital. When CSR activities such as health education, providing free services, and doing

Table 4. Sobel test for indirect relationship

\begin{tabular}{|l|c|c|l|}
\hline \multicolumn{1}{|c|}{ Path } & Indirect Effect & p-value & \multicolumn{1}{c|}{ Evaluation } \\
\hline $\mathrm{CSR} \rightarrow$ Loyalty $\rightarrow$ Value & 0.052 & 0.006 & Accepted \\
\hline $\mathrm{CSR} \rightarrow$ Reputation $\rightarrow$ Loyalty $\rightarrow$ Value & 0.161 & $* * *$ & Accepted \\
\hline
\end{tabular}

${ }^{\star}$ Calculated using Sobel test, ${ }^{* *}$ Significance value $<1 \%$

Table 5. Direct, indirect, and total effect

\begin{tabular}{|l|l|l|c|c|c|}
\hline Independent Variable & Dependent Variable & Mediating Variable & Direct Effect & Indirect Effect & Total Effect \\
\hline CSR & Loyalty & Reputation & 0.073 & 0.110 & 0.183 \\
\hline CSR & Reputation & & 0.155 & 0.155 \\
\hline Reputation & Loyalty & & 0.707 & & 0.707 \\
\hline Loyalty & Value & & 0.735 & & 0.735 \\
\hline Reputation & Value & Loyalty & 0.173 & 0.520 & 0.707 \\
\hline CSR & Value & Loyalty; Reputation & -0.084 & 0.161 & 0.077 \\
\hline
\end{tabular}


devoted work are well perceived by the patients, in their minds it is also attached to the stronger reputation of the hospital. Reputation is associated with a good impression of the service, impression of service reliability, the impression of the service perception, the impression of good management, and most importantly a general good impression by stakeholders. Therefore, in order to gain much more reputation in public, government hospital must leave positive impression to their CSR act. The better their CSR activities perceived by patients, the better their reputation will be gained.

\section{Direct effect of CSR on patients' loyalty}

CSR activities applied by hospital and perceived by patient are more likely able to encourage patient loyalty. The results showed that statistically CSR will create patient loyalty to government hospitals in Medan. Patients, as part of the stakeholders, will interact directly with the CSR activities undertaken by hospital. Moreover, unlike common characteristics of CSR in the non-health sector, many of the hospital's CSR activities indeed take place in the hospital environment itself. Thus, the customer as an inpatient will become the first party to have opportunities to interact with CSR activities implemented. This activity will make people trust more in these activities. This result is in line with the studies of Chung et al. (2015), and Ailawadi et al. (2014), though these studies were not conducted specifically in the health sector.

Moreover, the results of this study are also consistent with Diallo and Lambey-Checchin (2017), demonstrating the positive impact of CSR on customer loyalty. When CSR conducted by government hospitals is positively perceived by inpatients, they increasingly show loyal behavior. They become more confident in communicating the good experience at the hospital and recommend it to their colleagues, as well as indicate the use of health care services in the future. Our finding showed that even though the statistical result of path coefficient is relative small (less than 0.1), CSR is significantly able to affect the patients' loyalty. Hence, patients will get more loyal to the government hospital as they perceived a better CSR activities implemented.

\section{Direct effect of CSR on hospital value}

The results indicate that CSR has a direct, negative and significant influence on the hospital value. The result imply that CSR activities, given there is no impact on reputation and loyalty, will reduce the overall hospital value. The results indicate that CSR has a direct and negative influence on the hospital value. This is seemingly caused by the budget implementation of CSR activities with regard to the imposition of operating costs that would make the patients perceive that the hospital will financially deteriorate at a given level. This result is consistent with Srivastava et al. (2012), suggesting that CSR does not always have a positive impact on hospital values. Although it is in its initial development, CSR would impose relatively large additional costs, though, in the end, the hospital CSR would provide benefits by increasing levels of effectiveness and efficiency of services in addition to improved financial performance hospital through the presence of a more skilled medical personnel and the potential for more patients. CSR alone can be perceived in negative thought such as inefficiency use of service time and personal resource, waste of operational fund, also inefficient schedule for the patients.

\section{Direct effect of reputation in patients' loyalty}

The result regarding the positive relationship between reputation and loyalty, is also supported by previous studies (e.g Ali et al. 2012, Helm and Tolsdorf 2013). Shirazi et al. (2013) stated that a strong brand identity, for example, a hospital that has a high reputation, is more likely to result in consumer confidence leading to the loyal behavior of consumers. Hence, hospitals can update medical equipment and training of medical workers to improve the effectiveness and efficiency of the healthcare services. Thus, the more reputable the hospital, the more loyal the patients.

\section{Direct effect of loyalty on hospital value}

Customer loyalty will improve hospital value. In accordance with Kotler and Keller (2012), we believed that a loyal customer will behave in three possible action, (1) repurchase, (2) retain, (3) recommend. Each act of loyal customer will improve hospital value. Basically a loyal customer will bring more customer while retain themselves. If hospitals had much more loyal customer, it will bring more value to the hospital. Loyal customer become a source of continuous income that can be used to improve hospital value. Hospital may improve their equipment or undergo training for medical staff which improve their effectiveness and efficiency level healthcare services. This result is consistent with previous research that states that loyalty is key in improving the value of business development (Haghkhah et al. 2013, Keiningham et al. 2008). The statistical analysis shows that loyalty is more likely able to improve the patients' perceived information regarding the financial aspect, effectiveness and efficiency of services, thereby improving the hospital value

\section{Direct effect of reputation on hospital value}

The statistical testing also shows that there is a positive and significant influence of hospital reputation on the perception of the hospital value. This is consistent with previous studies (Eccles et al. 2007, Cole 2012) highlighting the positive relationship between the reputation and 
value of the company. Reputation has an important role in the effort to attract the attention of consumers and new resources for the hospital. For example, doctors who are more skilled or better paramedics will join a hospital that has a high reputation. This will encourage the effectiveness and efficiency of health services that impact on the overall value improvement.

\section{Indirect effect of CSR on hospital value through loyalty}

According to our research, most of CSR activities were directed to the inpatients, thus they will be more likely to experience the CSR conducted by hospital. It became the moment of truth between patients, paramedics, and hospital. As the CSR program delivered smoothly, it is more likely improving the patients' loyalty. The more they loyal the more future financial flow source established to hospital. Loyal patient will be likely to repurchase the services while spreading positive feedback to other. Loyal patients will be taken care more effective and efficiently through patient database for references. Also, the financial flow can be used to improve equipment to operate more efficiently.

\section{Indirect effect of CSR on hospital value through reputation}

Reputation management (Susanto 2009) stated that some organization commit to do CSR to maintain their reputation. Gazzola (2014) stated that CSR not only maintaining the reputation but also improve hospital reputation on public opinion. As public opinion increased, it will bring new source of human resource to improve service quality and service delivered to the patients. They will be more effective and efficiently while delivering the healthcare services.

\section{Conclusion and implication}

This study provides some important considerations regarding the applicability of CSR in the health sector. The statistical testing of the study model provides empirical evidence that CSR plays an important role in the creation of value through the creation of a government hospital reputation and patient loyalty. It should be emphasized that by analyzing the Sobel test, the direct negative impact of CSR will be covered by the strengthening role of hospital reputation and patient loyalty variables. CSR activities can encourage loyalty and reputation of the hospital directly. Overall, CSR is more likely to promote the value of the government hospitals. Hence, CSR activities should be applied strategically and should be implemented with regard to the core business of the hospital. CSR also has to be communicated properly in the effort to create the reputation of the hospital. Implementation of CSR is highly recommended in direct contact with hospital stakeholders such as patients and paramedics. Therefore according to our research we may conclude that CSR on government hospital will improve the patients' loyalty, reputation, and overall value. However we should pay attention that CSR should be conducted with care.

\section{Acknowledgment}

The study is fully supported and funded by the Universitas Sumatera Utara under research grant of Non-PNBP USU 2017, No. 5338/UN5.1.R/PPM/2017, dated May 22, 2017.

\section{References}

Aguilera RV, Rupp DE, Williams CA, Ganapathi J (2007) Putting the $S$ back in corporate social responsibility: a multilevel theory of social change in organizations. Academy of management review 32 (3): 836-863. https://doi.org/10.5465/ AMR.2007.25275678

Ailawadi KL, Neslin SA, Luan YJ, Taylor GA (2014) Does retailer CSR enhance behavioral loyalty? A case for benefit segmentation. International Journal of Research in Marketing 31 (2): 156-167. https://doi.org/10.1016/j.ijresmar.2013.09.003

Ali I, Alvi AK, Ali RR (2012) Corporate reputation, consumer satisfaction and loyalty. Romanian Review of Social Sciences (3): 13-23.

Babiak K, Trendafilova S (2011) CSR and environmental responsibility: motives and pressures to adopt green management practices. Corporate social responsibility and environmental management 18 (1): 11-24. https://doi.org/10.1002/csr.229

Bear S, Rahman N, Post C (2010). The impact of board diversity and gender composition on corporate social responsibility and firm reputation. Journal of Business Ethics 97 (2): 207221. https://doi.org/10.1007/s10551-010-0505-2

Bhattacharya CB, Korschun D, Sen S (2009) Strengthening stakeholder-company relationships through mutually beneficial corporate social responsibility initiatives. Journal of Business ethics 85: 257-272. https://doi.org/10.1007/s10551-008-9730-3

Bontis N, Booker LD, Serenko A (2007) The mediating effect of organizational reputation on customer loyalty and service recommendation in the banking industry. Management decision 45 (9): 1426-1445.

Boshoff C, Gray B (2004) The relationships between service quality, customer satisfaction and buying intentions in the private hospital industry. South African journal of business management 35 (4): 27-37.

Brandao C, Rego G, Duarte I, Nunes R (2013) Social responsibility: a new paradigm of hospital governance? Health Care Analysis 21 (4): 390-402. https://doi.org/10.1007/s10728012-0206-3

Budiharseno RS (2017) Factors affecting online buying behavior on g-market site among international students in Busan: a qualitative research. Arthatama: Journal of Business Management and Accounting 1 (1): 1-5.

Carroll AB (1991) The pyramid of corporate social responsibility: toward the moral management of organizational stakeholders. Business horizons 34 (4): 39-48. https://doi. org/10.1016/0007-6813(91)90005-G 
Carroll AB, Shabana KM (2010) The business case for corporate social responsibility: a review of concepts, research and practice. International journal of management reviews 12 (1): 85-105. https://doi.org/10.1111/j.1468-2370.2009.00275.x

Clarke J, Gibson-Sweet M (1999) The use of corporate social disclosures in the management of reputation and legitimacy: a cross sectoral analysis of UK Top 100 Companies. Business Ethics: A European Review 8 (1): 5-13. https://doi. org/10.1111/1467-8608.00120

Chung KH, Yu JE, Choi MG, Shin JI (2015) The effects of CSR on customer satisfaction and loyalty in China: the moderating role of corporate image. Journal of Economics, Business and Management 3 (5): 542-547.

Cole S (2012) The impact of reputation on market value. World Economics-Abingdon 13 (3): 47-68.

Dean DH (2003) Consumer perception of corporate donations effects of company reputation for social responsibility and type of donation. Journal of advertising 32 (4): 91-102. https:// doi.org/10.1080/00913367.2003.10639149

Diallo MF, Lambey-Checchin C (2017) Consumers' perceptions of retail business ethics and loyalty to the retailer: the moderating role of social discount practices. Journal of business ethics 141 (3): 435-449.

Doda S (2015) The importance of corporate social responsibility. Journal of Sociological Research 6 (1): 86-91. https://doi. org/10.5296/jsr.v6i1.7426

Eccles RG, Newquist SC, Schatz R (2007) Reputation and its risks. Harvard Business Review 85 (2): 104-114.

Fifka M (2012) The development and state of research on social and environmental reporting in global comparison. Journal für Betriebswirtschaft 62 (1): 45-84. https://doi.org/10.1007/ s11301-012-0083-8

Folajin OO, Ibitoye OT, Dunsin AT (2014) Corporate social responsibility and organizational profitability: an empirical investigation of United Bank for Africa (UBA) Plc. International Journal of Academic Research in Business and Social Sciences 4 (8): 205.

Frynas JG (2009) Corporate social responsibility in the oil and gas sector. Journal of World Energy Law \& Business 2 (3): 178-195. https://doi.org/10.1093/jwelb/jwp012

García de los Salmones Sánchez MDM, Crespo AH \&, del Bosque IR (2005) Influence of corporate social responsibility on loyalty and valuation of services. Journal of business ethics 61 (4): 369-385. https://doi.org/10.1007/s10551-005-5841-2

Gazzola P (2014) Corporate social responsibility and companies' reputation. Network Intelligence Studies 2 (3): 74-84. https:// doi.org/10.1007/s10551-005-5841-2

Geva A (2008) Three models of corporate social responsibility: interrelationships between theory, research, and practice. Business and society review 113 (1): 1-41. https://doi. org/10.1111/j.1467-8594.2008.00311.x

Gherghina SC, Vintila G (2016) Exploring the impact of corporate social responsibility policies on firm value: the case of listed companies in Romania. Economics \& Sociology 9 (1): 23-42. https://doi.org/10.14254/2071-789X.2016/9-1/2

Ghozali I (2011) Model persamaan struktural: Konsep dan aplikasi dengan program AMOS 19.0. Semarang: Badan Penerbit Universitas Diponegoro.
Grandón KLR and Reinoso LAA (2016) Social responsibility of healthcare organizations and the role of the nurse. In: Handbook of Research on Social Entrepreneurship and Solidarity Economics. IGI Global, 453-474. https://doi.org/10.4018/9781-5225-0097-1.ch022

Haghkhah A, Hamid AB, Ebrahimpour A, Roghanian P, Gheysari $\mathrm{H}$ (2013) Commitment and customer loyalty in business-tobusiness context. European Journal of Business and Management 5 (19): 156-164.

Handayani R, Wahyudi S, Suharnomo S (2017) The effects of corporate social responsibility on manufacturing industry performance: the mediating role of social collaboration and green innovation. Business: Theory and Practice 18: 152-159. https://doi.org/10.3846/btp.2017.016

Helm S, Eggert A, Garnefeld I (2010) Modeling the impact of corporate reputation on customer satisfaction and loyalty using partial least squares. In: Vinzi VE, Chin WW, Henseler J, Wang H (Eds) Handbook of partial least squares: concepts, methods and applications. Springer, 515-534. https://doi. org/10.1007/978-3-540-32827-8_23

Helm S, Tolsdorf J (2013) How does corporate reputation affect customer loyalty in a corporate crisis? Journal of Contingencies and Crisis Management 21 (3): 144-152.

Inleh O, Bartlett JL, May S (2011) Corporate social responsibility and communication. In: Ihlen O, Bartlett JL, May S (Eds) The Handbook of Communication and Corporate Social Responsibility. Chichester: Wiley-Blackwell, 3-22. https:// doi.org/10.1002/9781118083246

Ismail M (2009) Corporate social responsibility and its role in community development: an international perspective. Journal of International Social Research 2 (9).

Keh HT, Xie Y (2009) Corporate reputation and customer behavioral intentions: the roles of trust, identification and commitment. Industrial marketing management 38 (7): 732-742. https://doi.org/10.1016/j.indmarman.2008.02.005

Keiningham TL, Aksoy L, Cooil B, Andreassen TW, Williams L (2008) A holistic examination of Net Promoter. Journal of Database Marketing \& Customer Strategy Management 15 (2): 79-90.

Khan HUZ (2010) The effect of corporate governance elements on corporate social responsibility (CSR) reporting: empirical evidence from private commercial banks of Bangladesh. International Journal of Law and Management 52 (2): 82-109. https://doi.org/10.1108/17542431011029406

Knight RF, Pretty DJ (2001) Reputation and value: the case of corporate catastrophes. London: Oxford Metrica.

Korkchi S, Rombaut A (2007) Corporate social responsibility: a case study on private and public corporations in Sweden. Bachelor thesis, Institution for Business Administration and Economics, South Stockholm University- Södertörn School of Economics and Business Studies (EcoBus). http://www. diva-portal.org/smash/get/diva2:16710/fulltext01

Kotler P, Keller KL (2012) Marketing management (14th ed). New Jersey: Prentice Hall.

Kotler P, Lee N (2008) Corporate social responsibility: doing the most good for your company and your cause. John Wiley \& Sons. 
Kurniawan R (2017) Effect of environmental performance on environmental disclosures of manufacturing, mining and plantation companies listed in Indonesia stock exchange. Arthatama: Journal of Business Management and Accounting 1 (1): 6-17.

Lai CS, Chiu CJ, Yang CF, Pai DC (2010) The effects of corporate social responsibility on brand performance: the mediating effect of industrial brand equity and corporate reputation. Journal of business ethics 95 (3): 457-469. https://doi.org/10.1007/ s10551-010-0433-1

Lee MDP (2008) A review of the theories of corporate social responsibility: its evolutionary path and the road ahead. International journal of management reviews 10 (1): 53-73. https://doi.org/10.1111/j.1468-2370.2007.00226.x

Lev B (2013) Corporate Social Responsibility: Doing Good or Wasting Shareholders' Money? http://people.stern.nyu.edu/ blev/presentations/Corporate\%20Social\%20Responsibility\%20 -\%20Jul\%202013.pdf.

Lima Crisóstomo V, de Souza Freire F, Cortes de Vasconcellos F (2011) Corporate social responsibility, firm value and financial performance in Brazil. Social Responsibility Journal 7 (2): 295-309. https://doi.org/10.1108/17471111111141549

Luo X, Bhattacharya CB (2006) Corporate social responsibility, customer satisfaction, and market value. Journal of marketing 70 (4): 1-18. https://doi.org/10.1509/jmkg.70.4.1

Mandhachitara R, Poolthong Y (2011) A model of customer loyalty and corporate social responsibility. Journal of Services Marketing 25 (2): 122-133. https://doi. org/10.1108/08876041111119840

Marin L, Ruiz S, Rubio A (2009) The role of identity salience in the effects of corporate social responsibility on consumer behavior. Journal of Business Ethics 84: 65-78. https://doi. org/10.1007/s10551-008-9673-8

McWilliams A (2000) Corporate social responsibility. Wiley Encyclopedia of Management.

Meyer JA, Silow-Carroll S, Kutyla TMLA, Stepnick LS, Rybowski LS (2004) Hospital quality: ingredients for success - overview and lessons learned. New York, NY: The Commonwealth Fund.

Morsing M, Schultz M (2006) Corporate social responsibility communication: stakeholder information, response and involvement strategies. Business Ethics: A European Review 15 (4): 323-338. https://doi.org/10.1111/j.1467-8608.2006.00460.x

Mostafa MM (2005) An empirical study of patients' expectations and satisfactions in Egyptian hospitals. International Journal of Health Care Quality Assurance 18 (7): 516-532. https://doi. org/10.1108/09526860510627201

Mukhopadhyay K, Prathima VG, Jayashree V (2014) Critical appraisal of work values of hospital leaders-a case study conducted in reputed private hospital, Bangalore. International Journal on Leadership 2 (1): 23.

Naidu A (2009) Factors affecting patient satisfaction and healthcare quality. International journal of health care quality assurance 22 (4): 366-381. https://doi.org/10.1108/09526860910964834

Nasieku T, Togun OR, Olubunmi EM (2014) Corporate social responsibility and organizational performance: a theoretical review. International Journal of Humanities, Social Sciences and Education 1(12), 106-114.
Nicklin W, Dickson S (2009) The value and impact of accreditation in health care: a review of the literature. Canada: Accreditation Canada.

Nugroho AH, Bakar A, Ali A (2017) Analysis of technology acceptance model: case study of Traveloka. Arthatama: Journal of Business Management and Accounting 1 (1).

Öberseder M, Schlegelmilch BB, Murphy PE (2013) CSR practices and consumer perceptions. Journal of Business Research 66 (10): 1839-1851. https://doi.org/10.1016/j.jbusres.2013.02.005

Pivato S, Misani N, Tencati A (2008) The impact of corporate social responsibility on consumer trust: the case of organic food. Business ethics: A European review 17 (1): 3-12. https:// doi.org/10.1111/j.1467-8608.2008.00515.x

Schermerhorn JR (2016) Management (6th Asia-Pacific Ed). Melbourne: Wiley.

Secchi D (2007) Utilitarian, managerial and relational theories of corporate social responsibility. International Journal of Management Reviews 9 (4): 347-373. https://doi.org/10.1111/ j.1468-2370.2007.00215.x

Semplici S (2011) The importance of 'social responsibility' in the promotion of health. Medicine, health care and philosophy 14 (4): 355-363. https://doi.org/10.1007/s11019-011-9329-9

Sen S, Bhattacharya CB (2001) Does doing good always lead to doing better? Consumer reactions to corporate social responsibility. Journal of marketing Research 38 (2): 225-243. https://doi.org/10.1509/jmkr.38.2.225.18838

Shirazi A, Lorestani HZ, Mazidi AK (2013) Investigating the effects of brand identity on customer loyalty from social identity perspective. Iranian Journal of Management Studies $6(2)$ : $153-178$.

Snider J, Hill RP, Martin D (2003) Corporate social responsibility in the 21st century: a view from the world's most successful firms. Journal of Business ethics 48 (2): 175-187. https://doi. org/10.1023/B:BUSI.0000004606.29523.db

Sobel ME (1982) Asymptotic intervals for indirect effects in structural equations models. Sociological Methodology, 290-312. https://doi.org/10.2307/270723

Srivastava AK, Negi G, Mishra V, Pandey S (2012) Corporate social responsibility: a case study of TATA group. IOSR Journal of Business and Management 3 (5): 17-27. https:// doi.org/10.9790/487X-0351727

Susanto AB (2009) Reputation-Driven Corporate Social Responsibility, Pendekatan Strategic Management dalam CSR. Jakarta: Erlangga.

Susanto AB (2012) The role of corporate social responsibility in enhancing corporate reputation. Social Responsibility Review 3: 26-33.

Tai FM, Chuang SH (2014) Corporate social responsibility. Ibusiness 6 (03): 117. https://doi.org/10.4236/ib.2014.63013

Tian Z, Wang R, Yang W (2011) Consumer responses to corporate social responsibility (CSR) in China. Journal of business ethics 101 (2): 197-212. https://doi.org/10.1007/s10551-0100716-6

Torugsa NA, O’Donohue W, Hecker R (2013) Proactive CSR: an empirical analysis of the role of its economic, social and environmental dimensions on the association between capabilities and performance. Journal of Business Ethics 115 (2): 383-402. https://doi.org/10.1007/s10551-012-1405-4 
Vlachos PA, Tsamakos A, Vrechopoulos AP, Avramidis PK (2009) Corporate social responsibility: attributions, loyalty, and the mediating role of trust. Journal of the Academy of Marketing Science 37 (2): 170-180. https://doi.org/10.1007/ s11747-008-0117-X

Wahyuni S, Ginting M (2017) The impact of product quality, price, and distribution on purchasing decision on the astra motor products in Jakarta. Arthatama: Journal of Business Management and Accounting 1 (1): 18.

Wall E (2008) Creating value through corporate social responsibility programs http://www.law.com/jsp/law/careercenter/ lawArticleCareerCenter.jsp?id=1202423541991.
Walsh G, Mitchell VW, Jackson PR, Beatty SE (2009) Examining the antecedents and consequences of corporate reputation: a customer perspective. British Journal of Management 20 (2): 187-203. https://doi.org/10.1111/j.1467-8551.2007.00557.x

Weiwei T (2007) Impact of corporate image and corporate reputation on customer loyalty: a review. Management Science and Engineering 1 (2): 57.

Wu CC (2011) The impact of hospital brand image on service quality, patient satisfaction and loyalty. African Journal of Business Management 5 (12): 4873. 